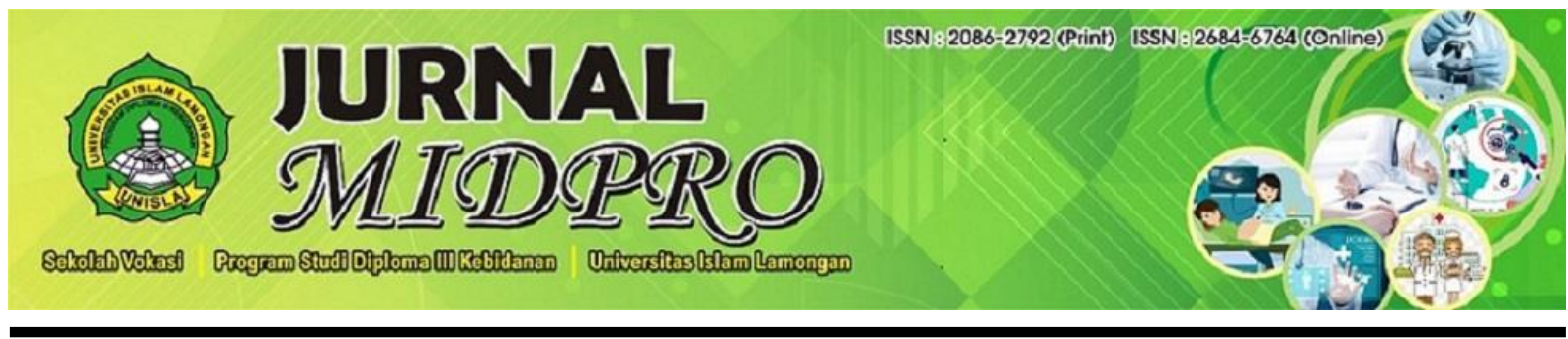

\title{
Healthy Living To Dismiss Covid-19 In Economic Crisis
}

$\mathbf{K}_{\mathbf{R}}$ Mochamad A $\mathbf{A}^{\mathbf{1}}$

${ }^{1}$ Departemen Magister Perbankan Syariah, Fakultas Ekonomi dan Bisnis, UIN Jakarta Email Penulis Korespondensi $\left({ }^{\mathrm{K}}\right)$ : hs.dynivi@gmail.com

\begin{abstract}
The study is aimed at analyzing how to live a healthy life in the Covid-19 and economics related to Islam and theory H. Health can affect one's economy, as growth in economic development will improve with a good quality of life. The approach used in this research is the research of the library through researching, analyzing, and reading the literature on how to lead a healthy life in Islam which is linked to Covid 19 and the economy. The results of the analysis show that on the importance of maintaining hygiene in everyday life, health and Islam have the same view. The economic crisis is the impact of Covid-19 to get a new normal life.
\end{abstract}

Keywords: Healthy life; Islam; Covid-1; Economics

\section{Article history :}

Received: 1 Juni 2020

Received in revised form: 1 September 2020

Accepted: 12 October 2020

Available online: 1 December 2020 


\section{INTRODUCTION}

Islam as a complete and ideal faith has set all the lifelong practices for its adherents in terms of both muamalah, fiqh, creed, and others. Islam also pays great attention to the health sector, as health is the key resource of everyday activities such as living, worshiping, and other activities.

Islam, which always stresses that everyone eats good and halal food, is one form of health appreciation by Islam because what we eat is one of the determinants of one's health. In QS Al-Baqarah, as the Word of Allah; 168 which means, "O people, eat halal food better than anything on earth. O believers, eat from what is good that we bless you".

Islam is a religion where people are strongly encouraged to live clean, safe, and environmentally friendly lives. Quite a few verses of the Qur'an and the Prophet's Hadith contain various messages relevant to those suggestions. Beginning with the idea that the body is washed, cooked, consumed halal and good food is prevented from harming nature and climate. Health with its balanced model can be used to include different knowledge relevant to the implementation of Islamic values, or vice versa so that from the point of health there is no difference between the glory of Islamic teachings and the conduct of daily life. The fundamental concept of this paradigm is the word of Allah SWT which states that Allah SWT produces nothing unless it benefits (QS 3:191). A high awareness of all God's creations that Ulul al-Bab (a group of people who believe and want to live and understand God's various creations) can accomplish ${ }^{1}$.

In the hadiths, Islam also advocates maintaining cleanliness because hygiene is the basis of health, and cleanliness is seen as part of faith in Islam itself. This is why Islamic teachings forbid habits this disregard cleanliness, such as littering, dumping of waste in rivers or wells where water does not flow, and the like since Islam also emphasizes cleanliness or At-thaharah. The health will be more awake with clean living habits because the disease often comes from a dirty environment aside from the stomach itself.

Strong Muslims are loved by Allah more than Muslims who are poor body strength can be obtained only with health and physical power, health is something we always ask of God for every time we pray, the Prophet's best Messenger who transmitted the message of Allah to his servant has provided many inspirations in their traditions, examines the Prophet's instructions, It seems we are opening up an area of research that is fascinating to be more scientifically studied regarding the Prophet's wellbeing how stable the Prophet's life is.

Aside from their commitment to science, Islam's concern for health is very strong. Unless the Islamic Sharia's main aim is to protect and maintain religion, spirit, reason, riches, and honor, all these things are difficult to achieve without health considerations. Religion and faith are human needs, human beings will do something without religion or faith and the rule of the jungle will happen. The soul is a priceless gift or life. Therefore Islam condemns and punishes those who take lives

There is a very close relationship between economics and wellbeing too. Economic development is very influential on the conditions of public health, and improvements to the conditions of public health 
will affect the productivity of work. Health is a condition of full physical, mental, and social well-being that is not limited to being disease-free or poor. One of the priorities to be accomplished in the national health system is to ensure the community's economic availability of reliable, inclusive, and accessible health services, and the provision of health services is not in the government's sole hands but requires the full active involvement of all community members.

Health is an important capital for carrying out daily activities, towards the blessings of God given to his servants, humans will find it difficult to perform routines that demand physical strength and endurance, a paradigm in society has now begun to shift from curative efforts to preventive health (prevention). Health is a very costly, gift from God. A healthy way of life in Islam as practiced by the Prophet is one of the preventive measures that we should make to preserve quality human capital to promote change in the economic field.

As Indonesia is experiencing at the moment, namely the economic weakening due to the pandemic (Covid 19). The Covid-19 pandemic is a coronavirus that originated and first emerged in late December 2019 from the city of Wuhan, China. The Covid-19 is suspected of coming from wild animals and having been tracked, people infected with this virus are people who have a history of visiting Wuhan, China's main wet seafood and livestock market. Until now, a cure for the virus has not been identified and it has swallowed many deaths in many countries like Indonesia and this virus has been described as a global pandemic that has affected nearly every country in the world. Jakarta is considered to be the distribution center in Indonesia, given the fact that DKI Jakarta is the capital of the Republic of Indonesia where the economy of the country is also based in this city. With the case continuing to grow, this epidemic continues to weaken the Indonesian economy from the rupiah's weakness against the US dollar, given the declining buying power of some commodities, panic purchases of staples resulting in shortages of staples and economists predict that economic recession will occur not only in Indonesia but also in other countries around the world.

Several hypotheses show the presence of Covid 19, beginning with the wet market in Wuhan, which markets a variety of wild animals for sale before some parties purposely create Covid 19 to decrease the human population of the planet. But the most strong theory to date still emerged in the Wuhan area, which sells wild animals for consumption. Considering that the laws relating to halal and haram foods are already limited in Islam, as are recommendations for a balanced lifestyle to prevent different diseases. Therefore the author is interested in further researching how Healthy Living in Islam and Theory $\mathrm{H}$ related to Covid 19 and economics, based on the context definition above.

\section{METHODS}

This study is focusing to explore the idea of Theory $\mathrm{H}$ relating to healthy living in Islam, Covid19, and the economy. This research is correlational, that is to say, research involving the compilation, selection, and determination of the relationship between two or more variables. The study was conducted 
for 2 months, starting in March 2020 through April 2020. This study's focus is to explore the idea of Theory H relating to healthy living in Islam, Covid-19, and the economy. This research is correlational, that is to say, research involving the compilation, selection, and determination of the relationship between two or more variables. The study was conducted for 2 months, starting in March 2020 through April 2020.

The researcher used secondary data obtained from different sources in this analysis. The use of secondary data is due to the researcher not taking the data directly, therefore is using data or documents provided by other parties. The data collected in this research was performed by collecting research information and data using literature review methods, such as exploration of literature, articles, and various journals both national and international. The data collected is data that has a relationship with a healthy way of life in Islam, H Theory, Co-19, and the economy.

Data analysis is a process of systematically and rationally selecting, simplifying, focusing, abstracting, organizing data by the research goals, and describing the results of the research data using tables as a tool for facilitating interpretation. The data analysis approach used in this study is a qualitative descriptive tool. The writer will describe the variables in the analysis in this case, and illustrate the interrelationships between the variables. The author will explain the research findings from multiple sources and conclude several papers and journals related to the study.

The data analysis technique used is the study of literature by gathering information relevant to the topic or problem that is the object of the research. It is possible to obtain this knowledge from books, research articles, theses, dissertations, encyclopedias, the internet, and other sources. There are at least four main characteristics in library research studies that the author must consider include: First, that the writer or researcher is dealing directly with text or numerical data, not direct field knowledge. Second, library data is "ready to use" which means that the writer does not go directly into the field because the researcher is directly dealing with the library's data source. Third, library data are generally secondary sources, in the sense that second-hand material or data is obtained by the authors and not the original data from the first field data. Fourth, that conditions in the data library are not limited by interest and time. Based on this, data collection in research is conducted through the examination and/or exploration of several journals, books, and documents (both printed and electronic) as well as other data sources and/or information deemed relevant to research or research.

The next step in the process of data processing and interpretation after all the data has been compiled, the writer attempts to assemble it inductively, which is based on particular rules and then translated into general laws. With this analysis technique, the author attempts to describe and analyze descriptively how to live a healthy life in Islam and $\mathrm{H}$ theory related to Covid-19 and the economy.

For graphical analysis, the images also need the help of quantitative data to explain the real problem more easily. The estimates in this research remain as part of systematic qualitative analysis, that is to say, this study aims to evaluate the statistical profile of data on positive people, victims who died and patients recovered from Covid-19 cases in Indonesia and worldwide. And researchers evaluated 
Covid-19's effect on the economic field, too. This statistical tool serves to reinforce the description by numbers when discussing the research's main problem.

\section{RESULT AND DISCUSSION}

Islamic scholarship must provide a basis for reasoning, as a theory to be applied in the field in line with scientific advancement at this time. There is a need for consistency between theories from the Koran and activities that exist in simulations and modern technology, so it needs a corridor in the form of a specific definition from the basic sciences of Islam itself.

In the five dimensions of an invariant arrangement, Narrowly Theory $\mathrm{H}$ is defined as the three dominant archetypal theory with a particular background. Broadly for the most general usage $\mathrm{H}$ Theory in the formation of such relationships can be viewed as a basic idea theory. $\mathrm{H}$ comes from the formula Hahslm, the letter from the Quran surah Hijr, which also stands for Huda or Life. H theory senses that a complete set / whole system / integrated component consists of 3 main components, namely primary (creator/intermediary), secondary (creation/receiver), tertiary (worship/transmitter), which can be charged either positively or negatively. These three elements will fulfill the assertion that secondary will do tertiary under primary (Man was made for worship by God) ${ }^{2}$.

The $\mathrm{H}$ theory is also an expression of the Islamic ideals that exist in humanity's everyday lives. Many facets of human life have to have material relevant to this theory of $\mathrm{H}$. The $\mathrm{H}$ theory, an embodiment of human beings, gods, worship has a broad meaning. If a person who is a Muslim wants to be at the peak of faith, he must have these guidelines. Theory $\mathrm{H}$ is a recent guide influenced by the Quran, in Islamic scholarship. The theoretical implications of this new theory for the development of science will add to the treasury of basic theory. And the reference to hardcore theory is not just Western theories or modern theories but can also apply to Islamic theories like $\mathrm{H}$ theory.

Islam is derived from the Arabic word 'Salama' meaning peace, pureness, surrender, and obedience $^{3}$. The simple word type consisting of 4 letters ( 3 letters +1 letter) is the most important basic word for the word Islam. In a simple equation then written: Islam is alif sinlammim. In the theory of $\mathrm{H}$ which is kaffah, from the following terms comes sin lam mim which has the sense of Existence, God, and Worship.

The three principles in the above $\mathrm{H}$ theory, if it is correlated with a healthy way of life in Islam is to pursue a healthy way of life in Islam particularly like the Prophet Muhammad PBUH then we preserve the health favors provided by Allah SWT. With good health quality, we can concentrate on worshiping God without feeling burdened and difficult.

The man was made on this earth not without the founder of SWT providing a specific reason and purpose. One of the human creature's purposes is to become a caliph on this planet, by God's word in Surah Al-Baqarah verse 30. The object of human existence, however, is not sufficient on this alone, but there are other missions that every human being must carry out through life on this planet, the goal is to 
worship and serve Allah SWT entirely only. It is in line with His teachings: "And I did not create the jinn and mankind except to worship Me (Q.S. Adh-Dhariyat verse 56).

With this verse, physical and spiritual worship must be safe and robust. Indirectly, the order to worship urges us to adopt a healthy lifestyle, as we will imitate, for example, the ways the Prophet Muhammad has done to preserve health. Despite their enthusiasm for research, Islam's health concern is very strong. If the main aim of Islamic law is to protect and sustain faith, life, reason, riches, and honor, all this cannot be done without regard to health ${ }^{4}$. Prompts for preserving health can be made with preventive (prevention) and punitive (elimination of illness or treatment) steps. Preventive, the health problem of Islam can be seen from the earnest guidelines for cleanliness preservation.

The societal shifts that are accompanied by technological growth in all facets of human life have both positive and negative impacts. Social changes that occur rapidly as a result of modernizing and globalizing, and advancing science and technology, have a serious impact in influencing the values of people's lives. Not everyone can adapt so easily to change, which in effect causes a feeling of laziness and tension that eventually leads to illness ${ }^{5}$. There are many ways to lead a safe life in Islam, from the Qur'an to the tradition of Prophet Muhammad, among others:

Eat nutritious foods recommended by Islam

The holy Qur'an recommends that people eat pure and legitimate foods mentioned earlier ${ }^{6}$. Eat things like:

\section{Grains}

The content of such food is good energy protein because it contains carbohydrates and fat. In addition to these foods do provide sources of $\mathrm{B}$ vitamin, vitamin $\mathrm{E}$, and vegetable protein. In QS God says. Al-Qaf verse 9 concerning seed nutrient source. "And We have sent down blessed rain from the sky and made grow thereby gardens and grain from the harvest" (Surah al-Qaf: 9).

2. Vegetables

Vegetables are plant foods that include root leaves, stems, seeds, or berries. These foods contain water, vitamin A, vitamin C, vitamin K, vitamin B, folate, and thiamine at 80-95 percent. Verse 24 of the suggestion that humans eat vegetables is suggested in the Qur'an QS. Yunus: "The example of [this] worldly life is but like rain which We have sent down from the sky that the plants of the earth absorb - [those] from which men and livestock eat - until, when the earth has taken on its adornment and is beautified and its people suppose that they have capability over it, there comes to it Our command by night or by day, and We make it as a harvest as if it had not flourished yesterday. Thus do We explain in detail the signs for a people who give thought".

Implement a healthy way of life that Rasulullah PBUH did:

1. Rasulullah is seated when he was about to drink

Rasulullah used to drink water first while sitting. It turns out that this approach is also proved clinically safe when there is a valve that is not able to accept water pressure where we drink water in a standing position, and where the valve is open and ready to absorb water when we sit. 
2. Rasulullah ate with his right hand

The Prophet said, which means, "If someone of you eats, he should eat with his right hand, because the devil eats with his left hand and he drinks with his left hand (HR, Muslim, Abu Dawud, and Ibn majah) ${ }^{7}$. According to a study, eating with the left hand often leaves the mind distracted and when you eat with the right hand, the active brain is the left brain where the essence of the left brain is still controlled and keeps thought. But if you eat with your left hand, then the right brain, which has an imaginary, random nature, is involved.

3. Rasulullah PBUH went to sleep quickly and woke up quickly

The Prophet Muhammad would fast sleep when it was time to sleep. And the normal night sleep after the break after the evening prayer, or about 21:30, is on. Then wake up at about 3:00 on a third of the night to pray in the evening. And there are less than eight hours spent sleeping. The use of 24-hour time in this context is as follows: a third to work, a third to worship God and another third to sleep.

4. Rasulullah PBUH often fasted

The properties and advantages have already been proved by several studies. According to a study, fasting is an effective restraining process. This is a safe way that people today don't know about. Sports as an effort to maintain health

Sport (Arabic: al-Riyadhat) belongs to the ijtihadiyat field, from the point of view of fiqh scholars. The law to do it is usually acceptable, it may even be worthy of worship if it is meant to worship or be able to do it completely, and its application is not contrary to Islamic norms ${ }^{8}$. Islamic teaching sources do not regulate the sport-related issues in detail, because they are worldly or ijtihadiyat, the form, technique, and rules are left entirely to humans or experts. Islam only lays down basic principles and guidelines to be obeyed in sporting activities. Al-Quran, which is used as a guide in the sense of the jihad, command to plan the strength to face the threat of enemy attacks, namely QS. Al-Anfal: 60.

Washing hands

In the Surah Al-Baqarah, verse 222 Allah says that it means: "Indeed, Allah loves those who are constantly repentant and loves those who purify themselves." The Messenger of Allah underlines this principle with his words which means: "Purity is a part of faith" 9

The hand is the organ that eliminates disease the most easily. On several occasions, Rasulullah PBUH has supported it. Washing both of them before meals became the prophet's practice when he started taking food ${ }^{10}$.

Consuming according to Islamic advice:

1. Not overdoing it

If it's forbidden for humans to overdo it, it means that humans will consume as required. (Surat alA'raf: 31) Based on this, the practice of reducing to nothing, showing off, buying unnecessary goods, is not an inappropriate activity of Islamic consumption in the economic language. Needs are not limited to personal or family needs but also the needs of our close fellow humans. As the 
Prophet's words (PBUH): "Except a believer when he is full while the neighbor next to him is hungry, even if he knows" ${ }^{11}$.

2. Consume halal and thayyib food

Food is the most important element for preserving health, as stated in health sciences or nutrition. Eating halal and thayyiban between Muslim medical experts ${ }^{12}$. The Quran tells people to pay attention to what they eat, as the verse states: "Then let mankind look at his food". (Surah "Abasa 80:24). The Prophet said "the stomach is a house of disease" we may infer that if the stomach is good, all good, thus consuming halal, real, (Living Food) not processed food, vegetable, and fruit intake, this must prevail over animals (flesh), otherwise the body will wear out quickly and lose. Islam always recommends consuming good food which Allah has provided them, namely the earth with its substance, and presumably, humans do not obey the kingdom and the traces of the shaitan who always tempts humans to want to forbid anything which Allah has permitted and forbidden the goodness which Allah has permitted; and Satan always wants humans to fall into the valley of errors in Q.S Al-Baqarah: 168.

With the existence of healthy lifestyles in Islam, we are encouraged to implement them in everyday life to avoid various diseases that attack our body, particularly the very vulnerable immune system of the body. Especially at a time like now that plagues Covid-19 in different countries around the world including Indonesia. Coronavirus, or extreme coronavirus 2 (SARS-CoV-2) acute respiratory syndrome, is a virus that affects the respiratory system. This disorder caused by a viral infection is known as COVID-19. This virus can lead to mild respiratory problems, serious lung infections, and death. A coronavirus is a new form of coronavirus distributed to humans. Coronaviruses (CoVs) are called Pikes that mimic crowns on their surface and belong to the Order of Nidovirales Coronaviridae family ${ }^{13}$. Coronavirus infects vast numbers of vertebrates including humans, birds, bats, rats, mice, and other wildlife.

Covid-19 was first discovered in China's city of Wuhan. The majority of coronaviruses infect and circulate in animals. Coronavirus causes a wide number of diseases in livestock and the potential in animals such as pigs, goats, horses, cats, and chickens to cause serious illness. Coronavirus is referred to as a zoonotic virus that is transmitted from animals to humans. Many wild animals can carry pathogens for some infectious diseases and serve as vectors for them. Hosts of Coronavirus include bats, bamboo rats, camels, and ferrets. This was later found, however, that the Coronavirus was also being transmitted from human to human. A person may contract Covid-19 in a variety of ways that involuntarily inhale droplets that come out when a Covid-19 patient coughs or sneezes, holds his mouth or nose without washing his hands first after touching an object affected by Covid-19 salivary splashes, close contact with Covid-19 patients. Until now, no vaccine has been found to cure Covid-19. Several attempts are ongoing to develop a vaccine, but it is estimated that it will take 18 months for the Covid19 vaccine to become available. Of the reported cases, fever, sore throat, and cough were identified as one with a history of travel to China or other areas of frequent local transmission or interaction with 
patients with similar travel history, or those with reported COVID-19 infection. The condition can however be asymptomatic or even without fever. Confirmed cases are cases for which positive molecular tests are suspected ${ }^{14}$.

Covid 19 emerged and has had so much power in various sectors. The economic field is one that is influenced and felt the most ${ }^{15}$. 'The Covid-19 pandemic has created an enormous uncertainty shock - larger than the one associated with the financial crisis of 2008-09 and more similar in magnitude to the rise in uncertainty during the Great Depression of 1929-1933.

It has been the current concern because, in recent months, Covid-19 has undermined the global economy as a whole. The United Nations Department of Economic and Social Affairs (UN-DESA) Because of the new Corona Virus pandemic or Covid-19, the global economy could shrink by one percent by 2020 and can contract further if economic activity restrictions are extended without adequate fiscal response. The UN-DESA briefing found that when nearly 100 countries close their national borders millions of workers risk losing their jobs. This could mean a global economic contraction of 0.9 percent by the end of 2020, or even higher if the government fails to provide income support and help increase consumer spending ${ }^{16}$.

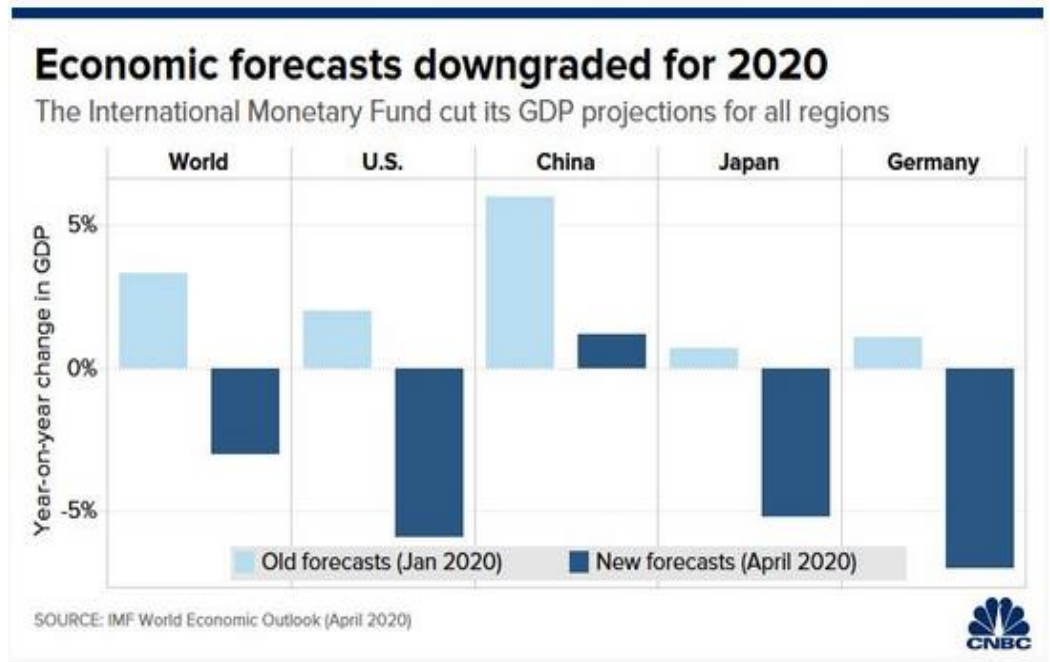

Picture 1. Economic Forecasts Downgraded

The pandemic of Covid-19 against economic activity has prompted many organizations to cut their global economic growth forecasts ${ }^{17}$. The IMF, whose economic assessment is commonly followed, forecasts this year that the global economy will contract by 3 percent. Just a handful of economies are projected to develop by 2020-like China and India. As the IMF's managing director Kristalina Georgieva says both parties need to work together, cooperate, and protect the most vulnerable. The IMF is now working with the World Bank and other financial institutions to overcome the economic downturn caused by the Covid-19 pandemic, which has infected more than 1 million people in different parts of the world and has killed over 55,000. IMF urges central banks in developed countries to support developing countries The IMF currently has up to $\$ 1$ trillion in funding and will use it as much as 
necessary. Several countries, in addition to the IMF, have committed themselves to issue a series of stimuli and funding to help drive the economy hit by the Covid-19 pandemic.

Based on data up to 2 March 2020, the mortality rate was 2.3 percent worldwide while it was 4.9 percent in Wuhan City and 3.1 percent in Hubei Province. This figure is 0.16 percent in other provinces in China.8.9 Based on a study of the first 41 patients in Wuhan, 6 people died (5 ICU patients and 1 non-ICU patient).

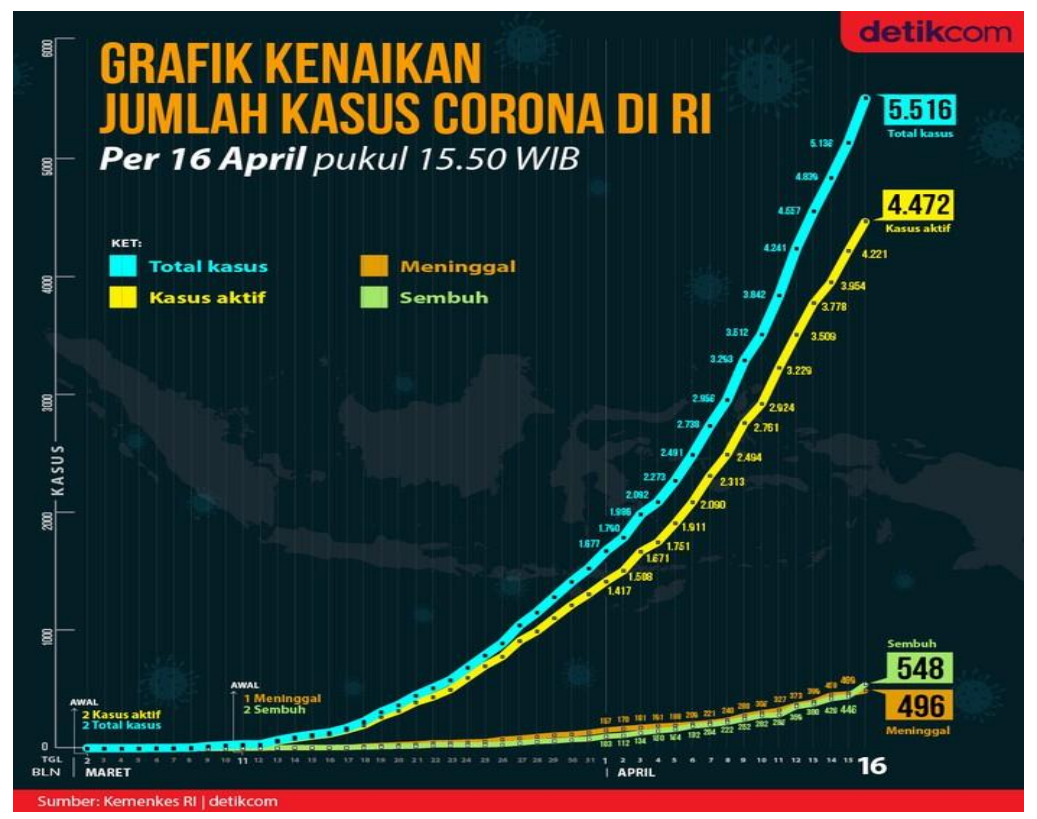

Picture 2. Graph of the Increase in the Number of Corona Cases in Indonesia

Above is a graph of case data Covid-19 in Indonesia from the Indonesian Ministry of Health on 16 April 2020 and then analyzed by the infographic team detik.com. The report indicates the number of surviving patients exceeds those who died.

Table 1. Covid-19 Statistics

\begin{tabular}{|c|c|c|c|}
\hline \multicolumn{4}{|c|}{ Table 1: COVID-19 statistics (as at 23 ${ }^{\text {rd }}$ April 2020) } \\
\hline Countries & $\begin{array}{c}\text { Confirmed cases } \\
(\text { Total) }\end{array}$ & $\begin{array}{c}\text { Confirmed Deaths } \\
\text { (Total) }\end{array}$ & $\begin{array}{c}\text { Recovered } \\
\text { (Total) }\end{array}$ \\
\hline Global & $2,656,391$ & 185,156 & 729,815 \\
\hline US & 849,092 & 47,681 & 84,050 \\
\hline Italy & 187,327 & 25,085 & 54,543 \\
\hline China & 82,798 & 4,632 & 77,207 \\
\hline Iran & 87,026 & 5,481 & 64,477 \\
\hline Spain & 213,024 & 22,157 & 89,250 \\
\hline Germany & 150,729 & 5,315 & 103,300 \\
\hline UK & 133,495 & 18,000 & - \\
\hline Canada & 40,190 & 1,974 & 13,986 \\
\hline France & 159,877 & 21,340 & 40,657 \\
\hline India & 21,797 & 681 & 8,376 \\
\hline South Korea & 10,702 & 240 & 16,477 \\
\hline Turkey & 98,674 & 2,376 & 4,891 \\
\hline Russia & 62,773 & 555 & 25,318 \\
\hline Brazil & 46,182 & 2,924 & 1,055 \\
\hline South Africa & 3,635 & 65 & 197 \\
\hline Nigeria & 873 & 28 & 38 \\
\hline Tunisia & 909 & \multicolumn{3}{|c|}{} \\
\hline $\begin{array}{l}\text { Source: Worldometer }{ }^{5} \text { Note that there may be unconfirmed cases which were never } \\
\text { reported to the public health authorities. }\end{array}$ \\
\hline \multicolumn{4}{|l}{}
\end{tabular}


Real-time data concerning the distribution of Covid-19 sourced from the Worldometer is attached in the table above. The following data reveals that the US has the largest number of people infected, followed by China, Italy, and Iran as of 23 April $2020{ }^{18}$.

Table 2. World Region Situation

\begin{tabular}{|l|c|c|c|c|}
\hline \multicolumn{5}{|c|}{ Table 2: World Region Situation in Numbers as of 23 ${ }^{\text {rd }}$ April 2020 } \\
\hline Region & Confirmed cases & New cases & Total Deaths & New deaths \\
\hline Global & $2,471,136$ & 73,920 & 169,006 & 6,058 \\
\hline European region & $1,219,486$ & 32,302 & 109,952 & 3,618 \\
\hline Region of the Americas & 925,291 & 32,172 & 44,775 & 2,089 \\
\hline Eastern Mediterranean & 139,349 & 4,879 & 6,326 & 141 \\
\hline Western Pacific Region & 136,271 & 1,765 & 5,793 & 108 \\
\hline South East Asia & 33,912 & 2,242 & 1,427 & 86 \\
\hline African region & 16,115 & 560 & 720 & 16 \\
\hline Source: World Health Organisation & \multicolumn{5}{|l|}{} \\
\hline
\end{tabular}

Regional data released by the WHO on the spread of coronavirus (or covid-19 disease) indicates that Europe had the most infected cases, followed by the Americas and the Eastern Mediterranean on 23 April 2020. Statistics as shown in table 2 above.

The government needs to ensure efficient and well-resourced public health programs to prevent infection and spread, and enforce well-targeted strategies to help health care services and staff while maintaining the incomes of vulnerable social groups and businesses during virus outbreaks.

The pandemic of the Covid-19 prompted governments around the world to update their budgets. They will set aside not-small funds to resolve the pandemic and its consequences. Indonesia is one of the countries that is also preparing a large budget to tackle Covid-19 pandemic impacts. In a press conference at President Joko Widodo announced the preparation of funds of up to Rp405.1 trillion (2.55\%) of GDP as an incentive for handling Covid-19. Of the total budget, Rp75 trillion of which will be used for health funds which are planned to be used for health workers, such as the purchase of personal protective equipment (PPE) and needed medical equipment such as test kits, reagents, ventilators, hand sanitizers, and so on. There is also a budget that will be intended as an incentive for medical personnel. Specialist doctors, for example, will get Rp. 15 million each month. General practitioners Rp. 10 million per month, nurses 7.5 million / month, and other health workers Rp. 5 million / month. There is also a death benefit to the family of medical personnel in the amount of Rp. 300 million. Aside from health workers, the budget will also be used to improve health facilities in 132 referral hospitals for handling Covid-19 patients. 


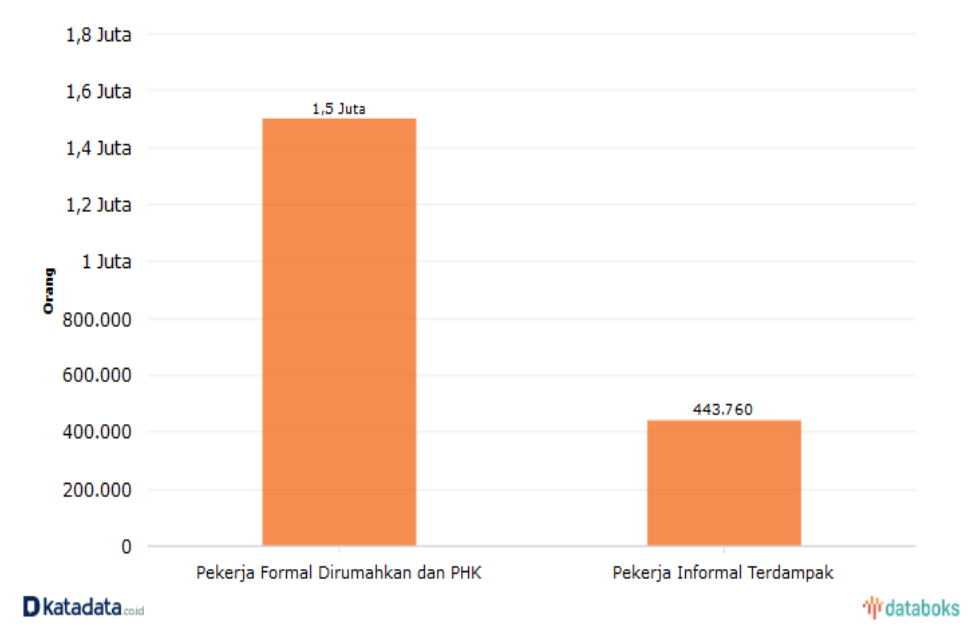

Picture 3. Directorate-General for Industrial Relations Development and Labor Social Security

Source: Ministry of Manpower (April 16, 2020) which is processed again by Katadata.co.id

Covid-19 also affected more laid-off and laid-off jobs. The Ministry of Manpower's DirectorateGeneral for Industrial Relations Development and Labor Social Security recruited 1,94 million workers from 114,340 firms laid off and laid off ${ }^{19}$. More specifically, of 83,546 companies, as many as 1,500,156 workers came from the formal sector. The informal sector has also been affected, in addition to the formal sector. Of 30.794 businesses, 443.760 employees were affected.

\section{CONCLUSION}

Islam as a complete and ideal faith has set all the lifelong practices for its adherents in terms of both muamalah, fiqh, creed, and others. Islam also pays great attention to the health sector, as health is the key resource of everyday activities such as living, worshiping, and other activities. Islam's health dimension is very much required so that all Muslims can carry out their worship and daily activities without the slightest hurdle. We are expected to be able to follow healthy Islamic ways of living such as: eating nutritious foods recommended by Islam (full grains and vegetables), implementing a healthy lifestyle performed by Rasulullah PBUH, exercise as an effort to maintain health, wash hands and consume according to Islamic advice.

In an age like now that plagues the Covid-19 virus, adopting a healthy lifestyle is highly recommended to protect the body's immunity. Also, there are several appeals and regulations issued by the central and regional governments concerning attempts to break the chain of Covid-19's spread. And as is well known the spread of the Covid-19 virus by spitting saliva or droplets from Covid-19 sufferers is very simple and fast. Hence it is recommended that we always practice cleanliness by, for example, regularly washing hands and also keeping a safe lifestyle so that the immunity of our body can combat different viruses. When we look back, it turns out that Islam has taught and controlled it all long before the Covid-19 virus since Islam rahmatan lil alamin is an integral part of the essence of living structures that reside in humans, the world, and the cosmos, meaning that all life starts with the great principle of 
Islam. When, according to Islam, all Muslims, including us, have a safe way of life, including what the Prophet PBUH did, then God willing, our body's immunity can withstand a variety of diseases.

With Covid-19's increasingly widespread outbreak in various countries including Indonesia, the impact on various aspects, particularly the economic ones. The central and national governments adopted different policies to deal with the outbreak of the Covid-19, starting with the introduction of Large-Scale Social Restrictions (PSBB) in many cities to prohibit all migrants from going home knowing that the Eid celebration is coming soon for Muslims. Indonesian Finance Minister Sri Mulyani predicts that economic growth would fall to $2.3 \%$, but in the worst case, it could reach $0.4 \%$. This was attributed to a dramatic fall in household consumption and expenditure. Covid-19 also affected more laid-off and laid-off jobs.

\section{REFERENCES}

1. Ratodi M. Integrasi Konsep Islam dalam Konteks Promosi Kesehatan. Al-Mabsut J Stud Islam dan Sos. Published online 2015.

2. Aziz RM. Teori H dalam Islam Sebagai Wahyu dan Turats. J Ushuluddin UIN Riau . 2016;24(1):103-120. doi:http://dx.doi.org/10.24014/jush.v24i1.1347

3. Ar A, Aidalina M. a Review of the Islamic Approach in Public Health Practices. Int J Public Heal Clin Sci. Published online 2014.

4. Asyhari M. KESEHATAN MENURUT PANDANGAN AL-QUR'AN. ALQALAM. Published online 2005. doi:10.32678/alqalam.v22i3.1369

5. Jauhari I. Kesehatan dalam pandangan Islam. Kanun J Ilmu Huk. Published online 2013. doi:ISSN: 0854-5499

6. Edriss H, Rosales BN, Nugent C, Conrad C, Nugent K. Islamic Medicine in the Middle Ages. Am J Med Sci. Published online 2017. doi:10.1016/j.amjms.2017.03.021

7. Anam K. Pendidikan Perilaku Hidup Bersih dan Sehat dalam Prespektif Islam. J Sagacious. Published online 2016.

8. Khairuddin. Olahraga Dalam Pandangan Islam. J Olahraga Indragiri. Published online 2017.

9. Abidin Z. KELUARGA SEHAT DALAM PERSPEKTIF ISLAM. KOMUNIKA J Dakwah dan Komun. Published online 1970. doi:10.24090/komunika.v6i1.346

10. Fadli SNIA, Mokhtar WKAW, Amiruddin E, Rashid RA, Idris MFHM, Salleh AZ. Healthy Lifestyle of Prophet Muhammad S.A.W. Int J Acad Res Bus Soc Sci. Published online 2019. doi:10.6007/ijarbss/v9-i11/6578

11. Sitepu NI. PERILAKU KONSUMSI ISLAM DI INDONESIA. J Perspekt Ekon DARUSSALAM. Published online 2017. doi:10.24815/jped.v2i1.6650

12. Qardhawi Y Al. Halal Dan Haram Dalam Islam.; 2001.

13. Yang Y, Peng F, Wang R, et al. The deadly coronaviruses: The 2003 SARS pandemic and the 
2020 novel coronavirus epidemic in China. J Autoimmun. Published online 2020. doi:10.1016/j.jaut.2020.102434

14. Singhal T. A Review of Coronavirus Disease-2019 (COVID-19). Indian J Pediatr. Published online 2020. doi:10.1007/s12098-020-03263-6

15. Baker S, Bloom N, Davis S, Terry S. COVID-Induced Economic Uncertainty. Natl Bur Econ Res. Published online 2020. doi:10.3386/w26983

16. Jiang F, Deng L, Zhang L, Cai Y, Cheung CW, Xia Z. Review of the Clinical Characteristics of Coronavirus Disease 2019 (COVID-19). J Gen Intern Med. Published online 2020. doi:10.1007/s11606-020-05762-w

17. OECD. Coronavirus: The world economy at risk. OECD Interim Econ Assess. Published online 2020.

18. Ozili PK, Arun T. Spillover of COVID-19: Impact on the Global Economy. SSRN Electron J. Published online 2020. doi:10.2139/ssrn.3562570

19. Yuliana. Corona Virus diseases (Covid-19). Wellness Heal Mag. Published online 2020. 